\title{
PENINGKATAN AKTIVITAS BELAJAR IPSMELALUI STRATEGI PEMBELAJARAN AKTIF TIPE TEAM QUIZ
}

\author{
Felix Welu', Berty Sadipun ${ }^{2}$, Frumensius Dole ${ }^{3}$ \\ Universitas Flores ${ }^{1,2,3}$ \\ sariyyah.nining@gmail.com ${ }^{1}$
}

\begin{abstract}
ABSTRAK
Penelitian ini bertujuan untuk mengetahui peningkatan aktivitas belajar siswa melalui strategi pembelajaran aktif tipe Team Quiz. Penelitian ini menggunakan pendekatan Penelitian Tindakan Kelas (PTK). Subyek penelitian ini adalah 22 orang siswa Kelas IV SDI Bhoanawa 1. Teknik pengumpulan data dilakukan dengan metode observasi, catatan lapangan dan wawancara. Hasil penelitian menunjukkan adanya peningkatan aktivitas belajar siswa. Hal ini dibuktikan dari perolehan persentase keaktifan pada siklus I sebesar $62 \%$ dengan kategori cukup aktif menjadi $76 \%$ dengan kategori aktif pada siklus kedua. Simpulan, strategi pembelajaran aktif tipe team quiz dapat meningkatkan akativitas belajar IPS
\end{abstract}

Kata Kunci: Aktivitas Belajar, Strategi Pembelajaran Aktif, Tipe Team Quiz

\begin{abstract}
The study was to know the improvement of students learning activities by using active learning method by the application of Team Quiz. The study was a classroom action research. The subject was 22 students from grade IV SDI Bhoanawa 1. The data collection was conducted through observation, field note and interview. The result showed the improvement of students learning activities. It was proved by the percentage score of the activities in cycle I for $62 \%$ with category 'quite active' and $76 \%$ in cycle II with category 'active'. In conclusion, active teaching strategy with team quiz can improve social learning activities.
\end{abstract}

Keywords: Teaching Activities, Active Teaching Strategy, Team Quiz

\section{PENDAHULUAN}

Salah satu masalah pokok dalam pembelajaran pada pendidikan formal (sekolah) dewasa ini yaitu masih rendahnya daya serap peserta didik yang nampak pada hasil belajar peserta didik karena kurangnya startegi pembelajaran yang digunakan. Proses ini menjadikan guru lebih mendominasi dan kurang memberikan kesempatan pada peserta didik untuk bertanya dan menemukan masalah yang dihadapinya dalam setiap mata pelajaran. Untuk itu guru perlu menciptakan kondisi 
belajar yang memungkinkan terjadinya proses interaksi yang baik dengan peserta didik agar mereka dapat melakukan berbagai aktivitas belajar dengan efektif sehingga hasil belajar yang mereka peroleh akan maksimal (Asrori, M, 2007).

Berdasarkan hasil observasi pembelajaran IPS yang dilakukan peneliti pada kelas IV di SDI Bhoanawa 1 menunjukkan aktivitas belajar siswa yang masih rendah.Hal ini dikarenakan pola belajar siswa yang cenderung teachercentered. Kondisi ini menjadikan peserta didik lebih dominanmelakukan aktivitas lain dari pada menyimak penjelasan guru. Padahal pembelajaran bisa berjalan dengan baik apabila ada interaksi antara guru dan peserta didik.Masalah yang dihadapi adalah ketidaksesuaian dalam penerapan strategi maupun media pembelajaran oleh guru yang sesuai materi pembelajaran sehingga aktivitas belajar peserta didik menjadi rendah.

Pembelajaran aktif sangat perlu diterapkan karena untuk dapat memperbaiki kulitas proses pembelajaan sehingga diharapkan dapat meningkatkan aktivitas dan pemahaman siswa. Belajar aktif merupakan sebuah kesatuan sumber kumpulan strategi-strategi pembelajaran yang komprehensif (Silberman dalam Pratiwi dkk, 2016). Belajar aktif meliputi berbagai cara untuk membuat peserta didik aktif sejak awal melalui aktivitas-aktivitas yang membangun kerja kelompok dan dalam waktu singkat membuat mereka berpikir tentang materi pelajaran. Oleh karena itu, guru harus menerapkan strategi pembelajaran yang tepat untuk meningkatkan aktivitas belajar peserta didik secara optimal.

Salah satu tipe strategi belajaraktif yang dapat diterapkan adalah strategi Team Quiz. Strategi belajar aktif tipe Team Quiz Menurut Zaini (dalam Hamruni, 2012), strategi pembelajaran Team Quiz adalah strategi yang dapat meningkatkan kerja sama tim dan sikap tanggungjawab peserta didik dengan cara yang menyenangkan. Dengan diberikan tanggungjawab kepada peserta didik maka dapat memberikan umpan balik kepada peserta didik untuk lebih aktif. Proses belajar mengajar Team Quiz juga mengajak siswa bekerja sama dengan teamnya dalam melakukan diskusi bertanya, menjawab pertanyaan, memberi arahan, mengemukakan pendapat, serta menyampaikan informasi (Silberman dalam Purnama dan Afriansyah, 2016).

Team Quiz juga dapat meningkatkan semangat dan pola pikir kritis siswa. Pada strategi ini, siswa dibagi ke dalam beberapa kelompok. Semua anggota bersamasama mempelajari materi tersebut kemudian diadakan suatu pertandingan akademi. Dengan ini diharapkan dapat meningkatkan kemampuan tanggug jawab siswa terhadap apa yang mereka pelajari melalui cara yang menyenangkan (Lestari, 2017). 


\section{METODE PENELITIAN}

Dalam penelitian ini, peneliti menggunakan pendekatan Penelitian Tindakan Kelas (PTK). Penelitian ini dimaksudkan untuk mengetahui aktivitas belajar peserta didik pada pembelajaran IPS kelas IV di SDI Bhoanawa 1 Kecamatan Ende Selatan Kabupaten Ende. Penelitian Tindakan Kelas dalam pandangan Mc Niff (dalam Asrori, 2007: 4) adalah penelitian reflektif yang dilakukan oleh guru sendiri yang hasilnya dapat dimanfaatkan sebagai alat untuk pengembangan dan perbaikan pembelajaran.

Penelitian ini dilaksanakan di ruangan kelas IV SDI Bhoanawa I Kecamatan Ende Selatan Kabupaten Ende yang Berjumlah 22 orang. Untuk melengkapi data-data yang diperlukan dalam penelitian ini, maka peneliti menggunakanteknik observasi, catatan lapangan dan dokumentasi. Observasi dilakukan dengan memperhatikan indicator keaktifan menurut Sudjana (2005), yakni turut serta melaksanakan tugas, terlibat dalam pemecahan masalah, bertanya apabila tidak mengerti, dan melaksanakan diskusi kelompok sesuai petunjuk guru.

Data dianalisis dengan membandingkan perolehan persentase keaktifan setiap siklus. Apabila perolehan persentase menunjukkan kriteria sangat atau aktif maka strategi pembelajaran aktif tipe Team Quiz dapat meningkatkan aktivitas belajar siswa. sehingga penelitian tidak perlu dilanjutkan ke siklus berikutnya.

\section{HASIL PENELITIAN}

Penelitian ini dilaksanakan dalam dua siklus melalui tahap perencanaan, tahap tindakan, tahap observasi dan tahap refleksi. Tahap perencanaan dilakukan dengan menentukan waktu dan jadwal pelaksanaan penelitian, mempersiapkan materi ajar yaitu tentang jenis-jenis pekerjaan, membuat Rencana Pelaksanaan Pembelajaran (RPP), menyiapkan Lembar Kerja Peserta Didik (LKPD), menyiapkan soal evaluasi (post test), dan lembar observasi penerapan Team Quiz dan aktivitas peserta didik yang digunakan dalam proses pembelajaran.

Tahap tindakan dilakukan dengan menerapkan strategi Team Quiz sesuai RPP. Langkah-langkah penerapan tersebut meliputi tahap penjelasan materi tentang jenis-jenis pekerjaan.Kemudian peserta didik dibagi dalam tiga kelompok. Kelompok $\mathrm{A}, \mathrm{B}$, dan kelompok $\mathrm{C}$ kemudian guru menjelaskan tata cara dalam memberikan pertanyaan kepada kelompok A, B dan C. Dan kelompok yang diberikan pertanyaan siap menjawab pertanyaan yang diberikan.

Apabilakelompok tidak bisa menjawab maka pertanyaan dilemparkan ke kelompok lain. Setelah semua kelompok selesai memberikan pertanyaan guru membagi soal LKS kepada setiap kelompok. Peserta didik mengerjakan LKS yang diberikan oleh guru. kemudian masing-masing kelompok melaporkan hasil diskusinya didepan kelas dan peserta didik dari kelompok lain diberikan kesempatan 
untuk memberikan tanggapan kepada kelompok yang sedang melaporkan hasil kerjanya.

Guru menyempurnakan jawaban peserta didik. Guru bertanya jawab tentang hal-hal yang belum dipahami oleh peserta didik, kemudian bersama peserta didik meluruskan kesalapahaman dan membuat kesimpulan tentang materi yang telah dipelajari. Setelah membuat kesimpulan guru memberikan soal evaluasi untuk mengetahui daya serap peserta didik. Adapun hasil observasi siklus I dan siklus II dapat dilihat pada Tabel 1

Tabel 1

Persentase aktivitas siswa

\begin{tabular}{llrc}
\hline No & Indikator Aktifitas & Siklus 1 & Siklus 2 \\
\hline $\mathbf{1}$ & Turut serta melaksanakan tugas & 70 & 85 \\
$\mathbf{2}$ & Terlibat dalam pemecahan masalah & 59 & 70 \\
$\mathbf{3}$ & Bertanya apabila tidak mengerti & 60 & 73 \\
$\mathbf{4}$ & Melaksanakan diskusi kelompok sesuai & 60 & 75 \\
$\quad$ petunjuk guru & & \\
$\quad$ Rata-rata & $62 \%$ & $76 \%$ \\
\hline
\end{tabular}

Merujuk pada Tabel 1, rata-rata perolehan persentase aktivitas peserta didik sebesar62\% dengan kategori cukup aktif pada siklus 1.Perolehan tersebut meningkat pada siklus 2 menjadi $76 \%$ atau dalam kategori aktif. Sehingga penelitian dihentikan pada siklus 2 karena telah memenuhi target penelitian.

\section{PEMBAHASAN}

Berdasarkan Tabel 1 menunjukkan adanya peningkatan indicator aktivitas dari siklus 1 ke siklus 2. Pada indicator turut serta melaksanakan tugas, baik siklus 1 maupun siklus 2 menunjukkan perolehan persentase yang paling tinggi. Hal ini dikarenakan langkah pembelajaran dalam strategi Team Quiz adalah membentuk kelompok. Hal memberikan kesempatan kepada siswa untuk saling berinteraksi di dalam di dalam tim. Sehingga siswa yang kurang pandai menjadi lebih percaya diri dan lebih aktif.

Pada indicator terlibat dalam pemecahan masalah menunjukkan perolehan persentase terendah pada siklus 1 maupun siklus 2. Perolehan ini sesuai dengan fakta yang ditemukan selama proses pembelajaran yakni tidak semua siswa dalam satu tim dapat memecahkan persoalan yang dihadapi. Umumnya siswa yang prestasinya rendah lebih mengandalkan siswa yang berprestasi tinggi untuk memberikan solusi atas jawaban yang diberikan. Walaupun pencapaiannya belum mencapai kategori sangat tinggi, namun melalui strategi Team Quiz ini telah memberikan kesempatan kepada siswa untuk aktif terlibat dalam setiap pemecahan masalah. 
Indikator bertanya apabila tidak mengerti dan indicator melaksanakan diskusi kelompok memperoleh persentasi sebesar $60 \%$ pada siklus 1. Masing-masing indikator tersebut mengalami peningkatan sebesar $73 \%$ dan $75 \%$ pada siklus II. Secara menyeluruh rata-rata keaktifan siswa mengalami peningkatan dari siklus 1 sebesar $62 \%$ menjadi $76 \%$ pada siklus 2 . Atau dengan kata lain terjadi peningkatan aktifitas dari kategori cukup aktif pada siklus 1 menjadi aktif pada siklus 2 . Berdasarkan uraian tersebut dapat disimpulkan bahwa strategi belajar aktif tipe Team Quiz dapat meningkatkan aktifitas belajar siswa kelas IV SDI Bhoanawa 1.

\section{SIMPULAN}

Berdasarkan hasil penelitian, dapat disimpulkan bahwa strategi belajar aktif tipe Team Quiz dapat meningkatkan aktifitas belajar siswa kelas IV SDI Bhoanawa 1

\section{DAFTAR PUSTAKA}

Asrori, M. (2007). Psikologi Pembelajaan. Bandung: CV Wacana Prima Hamruni. (2012). Strategi Pembelajaran. Yogyakarta: Insan Madani

Lestari. (2017). Pengaruh Strategi Team Quiz terhadap Hasil belajar Matematika kelas IV SD 20 Pontianak Selatan. Jurnal Pendidikan dan Pembelajaran. Tersedia: Jurnal.untan.ac.id

Purnama \& Afriansyah. (2016). Kemampuan Komunikasi Matematis Siswa Ditinjau Melalui Model Pembelajaran Kooperatif Tipe Complete Sentence dan Team Quiz. Jurnal Pendidikan Matematika, 10(1). tersedia: https//:ejournal.unsri.ac.id

Pratiwi. (2016). Penerapan Metode Pembelajaran Quiz Team untuk Meningkatkan Aktivitas dan Prestasi Belajar Siswa pada Materi Kelarutan dan Hasil Kali Kelarutan di Kelas XI IPA 2 SMA Al Islam 1 Surakarta Tahun Ajaran 2014/2015. Jurnal Pendidikan Kimia. 5(1). Tersedia: http://jurnal.fkip.uns.ac.id.php/kimia

Sudjana, N. (2005). Penilaian Hasil Proses Belajar Mengajar. Bandung: PT Remaja Rosdakarya. 